\title{
A corporate sustainability maturity model for readiness assessment: a three-step development strategy
}

\author{
Yenny Sari, Akhmad Hidayatno and Amalia Suzianti \\ Department of Industrial Engineering, Universitas Indonesia, Depok, Indonesia, and \\ Markus Hartono and Harman Susanto \\ Department of Industrial Engineering, University of Surabaya, Surabaya, Indonesia
}

Received 11 October 2019 Revised 25 February 2020 Accepted 18 May 2020

\begin{abstract}
Purpose - One of the main challenges of organisations today is how to navigate their development into ideal sustainable organisations. However, each readiness level requires a different rubric of indicators. Therefore, this study develops a corporate sustainability maturity model (CSMM), which can be used by organisations to conduct self-assessments, identify their current sustainability maturity levels and transition into mature sustainable organisations.

Design/methodology/approach - This CSMM comprises various maturity domains, sub-domains and levels as well as a rubric of indicators for assessing the maturity of corporate sustainability. In its development, a systematic literature review examined existing maturity models, after which a pilot study, based on the literature review, content analysis and expert interviews, was used to create a prototype of the CSSM. Finally, the model was refined and expanded by considering practitioners' feedback and the tendencies of other sustainability maturity models.

Findings - On the basis of the findings, some Indonesian organisations conducted sustainability activities, without having a strategic plan. Moreover, the factors driving organisations to conduct sustainability efforts included external and internal pressure. However, typical factors, such as awareness of sustainability and organisational reputation gained from conducting sustainability activities, were insignificant in the sample.

Originality/value - This CSMM is the first sustainability maturity model developed for readiness assessment in an Indonesian context. Through this CSMM, organisations can determine their current readiness level of sustainability maturity and choose the correct indicators to help improve each sustainability domain in the matrix.
\end{abstract}

Keywords Corporate sustainability, Maturity model, Systematic literature review, Structural equation modeling

Paper type Research paper

\section{Introduction}

Considered an essential part of society, corporations are urged to be more responsible in managing their business processes in a sustainable manner, without compromising economic sustainability (Elkington, 1997). The economic activities of corporations have also been subject to increasing pressure from stakeholders, especially in regard to ecological and social sustainability (Epstein, 2008). Meanwhile, Garcia et al. (2016) stated that organisations can lower their impact on the environment and increase their contribution to society by incorporating corporate sustainability.

The discourses regarding how a corporation can incorporate sustainability initiatives, however, have changed over time. Young and Tilley (2006) claimed that corporate

The manuscript was funded by a grant from Universitas Indonesia [grant code: Hibah Q1Q2-2019] for submission financial support.

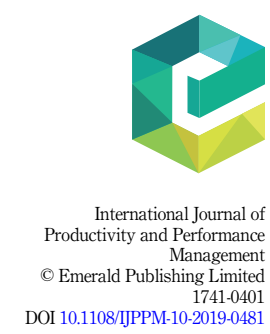

Corporate sustainability maturity model 
sustainability strategies have shifted from pollution control (from the 1960s to the 1970s) to eco- and social-efficiency (from the mid-1980s to the 1990s). Such examples include waste management, emission reduction and society engagement. In addition to eco- and socioefficiency, Dyllick and Hockerts (2002) mentioned the aspects of sufficiency and ecological equity in regard to sufficient consumption by individuals and continuity resources for future generations, respectively. Moreover, Epstein and Buhovac (2008) stated that the emphasis is no longer on whether organisations must consider sustainability issues and their consequences but on how organisations can integrate environmental, social and economic responsibilities into their day-to-day management decision-making. From an organisational perspective, this is the essence of corporate sustainability (Roca and Searcy, 2012).

Corporate sustainability has been defined as the equilibrium among economic returns (i.e. profits), environmental protection (i.e. the planet) and social development (i.e. the people), without endangering future development. According to Dyllick and Hockerts (2002), this term refers to being a sustainable corporation, which is not only consistent with the triple bottom line concept but is also a business orientation that meets stakeholders' needs over the long term. For Laszlo and Zhexembayeva (2011), there is an increasing need to embed sustainability into core business practices in order to contribute to sustainable development. Meanwhile, Edgeman and Williams (2014) described corporate sustainability as an organisation's capacity to create and maintain economic, environmental and social value for itself, its stakeholders and society at large, both in the short and long terms.

To date, it is still unclear how an organisation can assess the trade-off between sustainability and financial performance as well as determine how stakeholders will respond. Salzmann et al. (2005) stated that previous studies have attempted to explain the positive impact of the social dimension (i.e. the people) and the environment (i.e. the planet) on economic performance (i.e. profits). In this regard, the influence of the social dimension on financial performance mostly refers to the application of corporate social responsibility (Carroll and Shabana, 2010). Meanwhile, the studies conducted by Aras et al. (2010) and Michelon et al. (2013) proved that the practice of corporate sustainability (in the form of social responsibility) leads to better organisational performance as well as increased brand image and reputation. Moreover, the studies by Iraldo et al. (2009) and De Oliveira et al. (2010) showed that, through so-called green business processes, organisations can obtain economic benefits, including increased productivity, cost reductions and innovation. Conversely, Maletic et al. (2014) mentioned that efforts to conceptualise corporate sustainability practices are still rarely found in the literature. Epstein and Buhovac (2008) also stated that strategic level management has been unable to develop corporate sustainability, mainly due to the difficulty of focusing on financial performance, while achieving excellence in the 3Ps (i.e. the people, the planet and profits). As a result, many profit-oriented corporations have been neglecting the practice of corporate sustainability. Thus, a roadmap of how they can embrace sustainability practices is necessary in order to help them navigate their development into ideal sustainable organisations.

Indonesian corporations also face similar challenges in navigating towards sustainable practices. For example, as of October 2017, RobecoSAM's Corporate Sustainability Assessment ranked Indonesia 54th out of 65 countries, based on the environmental, social and governance dimensions of more than 2,000 companies and by weighting the interests of each dimension by $15 \%, 25 \%$ and $60 \%$ (RobecoSAM, 2017). More specifically, in the environmental dimension, RobecoSAM assesses environmental status, energy use and resources as well as environmental risk. As for the social dimension, the measurement indicators include employee welfare, equality, human development and local jobs. Meanwhile, the governance dimension holds the highest weight, which includes 
competitiveness, political risk, liberty and inequality, effectiveness, the rule of law, accountability, corruption, stability, regulatory quality, aging and institution.

The placement of Indonesia in the bottom 12 of RobecoSAM's ranking raises the question of whether it is associated with the low awareness of corporate sustainability implementation in the country as a whole. To date, no related publications have measured the awareness of corporate sustainability implementation in an Indonesian context. It is important to note, however, that such awareness cannot be simply measured through assessments and evaluations such as RobecoSAM's Corporate Sustainability Assessment.

According to a 2016 report by Ernst and Young Global Limited, only 30\% of the top 100 companies listed in the Indonesian Stock Exchange provided sustainability reports (MajalahCSR.id, 2017). However, after examining approximately 50 sustainability reports produced by Indonesian organisations from 2010 to 2017, several noteworthy observations can be made. First, the majority of the organisations have mistakenly considered corporate social responsibility programmes as corporate sustainability deeds, both in the form of community development programmes and philanthropic activities. This was most likely due to two reasons: (1) the Indonesian government's 1999 regulation requiring state-owned enterprises to conduct corporate social responsibility and (2) private organisations employing various corporate social responsibility programmes but mistakenly referring to them as corporate sustainability strategies. Second, according to the sustainability reports from 2005 to 2013, the industry sectors of Indonesian organisations that had participated in developing the sustainability reports were not only the organisations involved in exploring natural resources but also those in the infrastructure, consumer goods, banking, electronics and property sectors. Third, several Indonesian companies utilised comprehensive approaches and strategic frameworks that not only integrated sustainability strategies into their business processes but also synergised environmental alignment and community empowerment activities in order to achieve organisational profits. Finally, there were several organisations that conducted corporate sustainability activities through various approaches, models and interpretations, without producing sustainability reports or conducting sustainability assessments. On the basis of these findings, many Indonesian organisations are not fully aware of the importance of sustainability benefits.

In order to support organisations that want to grow their businesses more sustainably, they must strategise the implementation of corporate sustainability, which is normally part of the business process improvement strategy. According to Harrinton et al. (1997), this strategy includes systematic steps designed to improve business processes such as benchmarking, redesigning and process engineering. It also encourages more efficient workflow and overall business growth. Moreover, Adesola and Baines (2005) stated that this strategy requires several stages, the first of which is the readiness assessment stage. In this regard, the readiness of an organisation can be measured through a well-designed assessment tool, after which the results can serve as the foundation for improvement.

Previous literature review (Sari et al., 2019) has indicated that the development of sustainability assessment includes criteria-based and model-based approaches. Both approaches have their respective strengths and weaknesses. For example, it is easy for the criteria-based approach to formulate a series of indicators, but it may be difficult because of the similarities between certain indicators and subjectivity in the selection process. Meanwhile, although the model-based approach tends to formulate better indicators (since it refers to a validated model), it may be difficult to justify the ideals of the model. However, the model-based approach is more suitable than the criteria-based approach because the model not only acts as a distinguishing identifier between other models but also describes the dimensions, attributes and relationships between them.

On the basis of their literature review, Benmoussa et al. (2015) mentioned that models for business process assessments generally include two categories: performance measurement- 
driven and maturity measurement-driven models. As for their differences, performance measurement refers to utilising all organisational efforts (both efficiently and effectively) in order to achieve organisational goals and satisfy the customers and stakeholders. Performance measurements are usually based on performance indicators (Cerutti and Gattino, 1992). According to the Capability Maturity Model, maturity measurement refers to what extent specific processes are explicitly defined, managed, measured, controlled and improved (Paulk et al., 1995). Maturity measurements are generally based on the achievement of existing requirements at specified levels, i.e. the performance relative to the objectives at each maturity level (Benmoussa et al., 2015).

In terms of objectives, performance measurement-driven models (the most popular one being the Balanced Scorecard model) describe the process of gathering, analysing and presenting information about the performance of individuals, organisations or systems. In addition, a series of indicators, along with their targets and achievements, is generally used to monitor the progress of achieving certain strategies (Moullin, 2007; Kaplan and Norton, 2000). Conversely, maturity measurement-driven models are multistage conceptual models that describe systematic patterns and hierarchies in the development of organisational capabilities. Maturity models also identify the performance indicators at each maturity level that are achievable by organisations and their employees (Poppelbuss and Roglinger, 2011; Becker et al., 2009). Moreover, Comuzzi and Patel (2016) emphasised the two-fold benefits of maturity models, namely, descriptive and prescriptive benefits. Regarding the descriptive benefits, they describe the current achievements of organisations regarding specific capabilities. As for the prescriptive benefits, they highlight the necessary steps for improving organisational maturity. On the basis of these reasons, a maturity measurement-driven model is a more suitable approach for developing or expanding a corporate sustainability model.

Finally, the aforementioned study used the systematic literature review method (Tranfield et al., 2003; Morioka, 2016; Sari et al., 2019), which was carried out on two databases: (1) Science Direct (2010-2016), with the keywords sustainability indicators (or sustainability metric) and sustainability assessment (or sustainability performance or sustainability performance measurement), for a total of 875 potential articles (with no model addressing the measurement of the maturity aspect); and (2) Emerald (2013-2018), with the keywords Abstract: sustainability maturity model and Publication title: maturity, did not produce any potential article.

Thus, the motivation of this research work was formulated in the following research questions: (1) What is the framework of the corporate sustainability model that has been developed and published to date? Who is the root author, and what is the root theory related to the corporate sustainability model that will be the reference for developing the desired model?, (2) Is it true that there is still scarcity of research related to maturity models? What is the methodology for developing relevant maturity models? The identification of this gap is expected to be able to show the position and novelty of this study, (3) What is the conceptual framework of the Corporate Sustainability Maturity Model (CSMM), and how will the conceptual model be built? How do you use it as a readiness assessment tool for organisations in Indonesia?. Therefore, the purpose of this study is to obtain a conceptual model framework of the CSMM where the model can be used by organisations as a readiness assessment tool with two benefits at once, namely, descriptive and prescriptive objectives; organisations can conduct self-assessments to identify the current level of sustainability as well as obtain transition guidance to increase their level of maturity.

\section{Research methodology}

The proposed CSMM in this study includes a three-step development strategy, which is in line with the guidelines described by De Bruin et al. (2005) and Poppelbuss and Roglinger (2011). 
Overall, this strategy includes the stages of scoping, designing and evaluating. This method has also been adopted by Macchi and Fumagalli (2013) in their Maintenance Maturity Assessment, Jin et al. (2014) in their New Service Development Maturity Model and Comuzzi and Patel (2016) in their Big Data Maturity Model. More specifically, Comuzzi and Patel (2016) developed their maturity model qualitatively by conducting a literature review, performing semi-structured interviews with experts and allowing the model to be reviewed by practitioners. Similarly, Jin et al. (2014) developed their model qualitatively, by conducting a literature analysis and identifying the maturity domains in successful case studies. Conversely, Macchi and Fumagalli (2013) developed their model both qualitatively and quantitatively, by conducting a literature analysis and administering surveys to approximately 50 companies.

This mixed-method approach (Johnson et al., 2007) was also used in the present study's three-step development strategy. In this case, the qualitative aspects included content analysis and expert interviews, whereas the quantitative aspects consisted of structured questionnaires and structural equation modelling (SEM) analysis. Table 1 summarises this three-step development strategy.

As shown in Table 1, the first stage of development is scoping, the purpose of which is to map the maturity domains and levels relevant to the development of the CSMM. The methods used in this stage were a systematic literature review and a meta-analysis (Littell et al., 2008; Tranfield et al., 2013; Morioka and de Carvalho, 2016; Sari et al., 2019).

According to Figure 1, the systematic literature review began with a search for relevant articles in the Emerald database. In this case, the search filter included the abstract or research title, with terms related to the CSMM such as sustainability, corporate sustainability, maturity, maturity assessment, maturity model, sustainability maturity and sustainability maturity model. Another search filter was the publication period of January 2013 to July 2018. Overall, a total of 406 articles were obtained, after which a more in-depth reading of the abstracts, research methods, results and conclusions was performed to select appropriate articles and create the meta-analysis (Fifka, 2013). Only the papers that have described clearly the developed maturity model as well as its domains and levels will be selected for further meta-analysis.

The meta-analysis included summarising the results of the literature review and categorising the findings based on the type of maturity model, the research method approach (i.e. qualitative, quantitative or both), the industry, the title of the journal and the maturity domains and levels. This process produced 33 relevant articles ( $8.13 \%$ of the 406 articles). Finally, this stage used descriptive statistics to describe the results of the literature review, to
Corporate sustainability maturity model

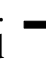




\section{IJPPM}

\section{Figure 1.}

The Scoping Stage based on the Systematic Literature Review and Metaanalysis (self-made)

\section{SEARCHING}

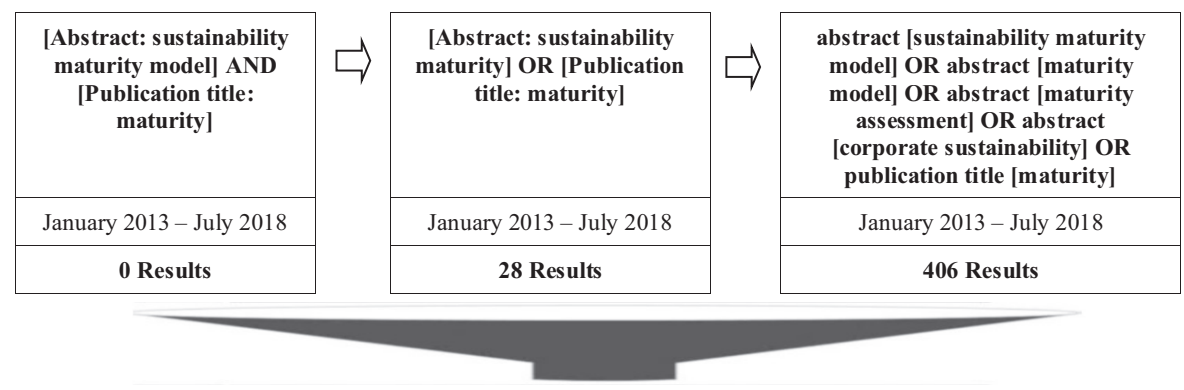

SELECTION

\begin{tabular}{|c|}
\hline Skimming the abstracts, introduction, research methodology and the result of maturity model \\
\hline $\mathbf{3 3}$ selected articles out of 406 \\
\hline
\end{tabular}

\section{DISSEMINATION}

Author (year), terms of maturity model, quantitative/qualitative approaches, industry, publisher, maturity domains and maturity level

Descriptive statistic tool; Special findings

map the development of the existing maturity models and to identify the maturity domains and levels.

The second stage of development is designing, which began with a pilot study based on the results of the literature review and by exploring the related root theory, e.g. Epstein's Corporate Sustainability Model (Epstein and Buhovac, 2008). This was followed by expert interviews and a content analysis of various sustainability reports and websites of several organisations.

Sari et al., 2019 had also found that corporate sustainability is one of the main concepts used by researchers to develop sustainability assessments. In this regard, it is important to examine Epstein's Corporate Sustainability Model (Epstein and Buhovac, 2008) and Blackburn's Sustainable Operating System (Blackburn, 2007). Both of these sources have commonalities in that they use the input-process-output approach. Epstein and Buhovac (2008) stated that the external context, internal context, business context and human and financial resources are the four inputs of leadership that will subsequently influence the preparation of a corporate sustainability strategy. Moreover, this strategy can be realised through organisational programmes, organisational systems and related efforts, all of which can improve sustainability performance. Meanwhile, Blackburn (2007) stated that a sustainability model consists of four main parts: drivers, efficient enablers, pathways and evaluators.

At this point, the following eight design questions (DQs) were formulated and used as a guide in the expert interviews:

$D Q 1$. In your opinion, what external factors are influential in the formulation of a corporate sustainability strategy?

$D Q 2$. What do you think are the internal factors that influence the formulation of a corporate sustainability strategy? 
DQ3. Do you think that there are other factors that influence the formulation of a corporate sustainability strategy?

DQ4. What aspects of the triple bottom line (i.e. profits, the planet and the people) are the maturity model priorities of your organisation?

DQ5. How does your organisation translate corporate sustainability strategy into corporate sustainability action?

DQ6. What type of corporate sustainability action does your organisation perform?

$D Q 7$. In your opinion, what are the benefits of implementing a corporate sustainability strategy?

DQ8. How do you measure the impact or influence of corporate sustainability strategy implementation?

The expert interviews involved three actors from Indonesian organisations whose implementation of a sustainability strategy gained some type of recognition (e.g. the Indonesia Green Award or the First Green Port recognition). The duration of the face-to-face interviews ranged from 1 to $2 \mathrm{~h}$, and the eight DQs were used to help the researchers understand the practical experiences of implementing a corporate sustainability strategy in the actors' respective organisations.

According to Krippendorff (2012), content analysis is a research technique used to make valid conclusions from textual materials. The purpose of such analysis is to describe the characteristics of a document's contents, including who said what, for whom the contents was addressed and what the effects were (Vaismoradi et al., 2013). In the present study, the content analysis was in line with Okongwu et al. (2013); that is, it determined whether the sustainability report or organisation website discloses the answers to the aforementioned DQs. Moreover, the selected organisations in the content analysis were manufacturing companies engaged in various fields, such as technology and consumer goods, with operations on a national and/or international scale. Overall, 10 organisations were selected (Table 2), including three domestic companies (Biofarma, Astra International and AQUA) and seven overseas companies with global operations.

Using the results of the literature review, expert interviews and content analysis, the conceptual framework for the CSMM, including the domains and sub-domains, was designed. It was then tested through SEM. Hair (2013) stated that there are two types of SEM: covariance-based SEM (CB-SEM) and partial least square SEM (PLS-SEM). In addition, Ghozali and Latan (2012) and Hair et al. (2017) stated the differences between the two methods as follows: CB-SEM is commonly used to confirm (or reject) a theory, e.g. the confirmation of a series of systematic relationships between multiple variables that can be empirically tested, whereas PLS-SEM is mainly used to develop a theory in exploratory research. The PLS-SEM method was selected to test the model because of its ability to test models with limited data, where the collected data can be small in size and non-parametric in nature, such that it does not have to be a normal distribution or based on normal distribution assumptions. As far as sample size is concerned, Barclay et al. (1995) and Chin and Newsted (1999) suggested a "rule of 10" to determine the sample size: 10 times the number of indicators in the largest latent variable or 10 times the largest number of incoming causal arrows for any latent variable in the model. Garson (2016) argued for the ability of PLS to handle small samples and be able to compute under very small samples condition (even less than 20).

Overall, the survey questionnaires included two parts. The first part included questions such as the name of the organisation itself, the respondent's position in the organisation, the number of employees, the industry sector, the organisation's age, ownership, scale marketing strategies and management system and the presence (or absence) of a corporate 


\section{IJPPM}

\begin{tabular}{|c|c|c|c|}
\hline No & $\begin{array}{l}\text { Organisations } \\
\text { (Country) }\end{array}$ & Description & Source \\
\hline 1 & Samsung (Korea) & $\begin{array}{l}\text { Samsung is one of the largest electronics companies in } \\
\text { the world }\end{array}$ & $\begin{array}{l}\text { Sustainability } \\
\text { Report } 2017\end{array}$ \\
\hline 2 & Apple (USA) & $\begin{array}{l}\text { Apple is a manufacturer of electronic equipment and } \\
\text { computer software }\end{array}$ & $\begin{array}{l}\text { Environmental } \\
\text { Report } 2017\end{array}$ \\
\hline 3 & $\begin{array}{l}\text { General Electric } \\
\text { (USA) }\end{array}$ & $\begin{array}{l}\text { General Electric is a multinational technology company } \\
\text { engaged in aviation, electricity, energy, health, lighting, } \\
\text { oil and gas, energy, transportation and capital }\end{array}$ & $\begin{array}{l}\text { Sustainability } \\
\text { Report } 2016\end{array}$ \\
\hline 4 & Qualcomm (USA) & $\begin{array}{l}\text { Qualcomm is a company that manufactures } \\
\text { semiconductors and telecommunications equipment }\end{array}$ & $\begin{array}{l}\text { Sustainability } \\
\text { Report } 2016 \\
\text { Company Website }\end{array}$ \\
\hline 5 & Biofarma (Indonesia) & $\begin{array}{l}\text { Biofarma is a state-owned enterprise that produces } \\
\text { vaccines and antisera }\end{array}$ & $\begin{array}{l}\text { Sustainability } \\
\text { Report } 2016\end{array}$ \\
\hline 6 & $\begin{array}{l}\text { Astra International } \\
\text { (Indonesia) }\end{array}$ & $\begin{array}{l}\text { Astra is a business group that includes seven business } \\
\text { lines: automotive, financial services, heavy equipment } \\
\text { and mining, agribusiness, infrastructure, logistics, } \\
\text { information technology and property }\end{array}$ & $\begin{array}{l}\text { Sustainability } \\
\text { Report } 2016\end{array}$ \\
\hline 7 & Toyota (Japan) & $\begin{array}{l}\text { Toyota is the largest automobile manufacturer in the } \\
\text { world }\end{array}$ & $\begin{array}{l}\text { Sustainability } \\
\text { Report } 2016\end{array}$ \\
\hline 8 & $\begin{array}{l}\text { Coca-Cola Company } \\
\text { (USA) }\end{array}$ & The Coca-Cola Company is a beverage manufacturer & $\begin{array}{l}\text { Sustainability } \\
\text { Report } 2016\end{array}$ \\
\hline 9 & $\begin{array}{l}\text { AQUA } \\
\text { Indonesia) }\end{array}$ & $\begin{array}{l}\text { The AQUA Group is a company that manufactures } \\
\text { bottled drinking water, with the most famous } \\
\text { trademark }\end{array}$ & $\begin{array}{l}\text { Sustainability } \\
\text { Report } 2014\end{array}$ \\
\hline 10 & $\begin{array}{l}\text { Procter and Gamble } \\
\text { (USA) }\end{array}$ & $\begin{array}{l}\text { Procter and Gamble is an international company that } \\
\text { produces fast-moving consumer goods }\end{array}$ & $\begin{array}{l}\text { Sustainability } \\
\text { Report } 2016 \\
\text { Company Website }\end{array}$ \\
\hline
\end{tabular}

Table 2.

Sources of documentary analysis
Samsung is one of the largest electronics companies in

Apple is a manufacturer of electronic equipment and computer software

Qualcomm is a company that manufactures

Report 2016

Company Website

Astra is a business group that includes seven business information technology and property

world

bottled drinking water, with the most famous trademark

produces fast-moving consumer goods
Report 2016

Company Website

sustainability strategy and/or a sustainability report. The second part contained a Likerttype scale that measured to what extent the respondent agreed with the corporate sustainability model's domains or sub-domains. This scale ranged from 1 (strongly disagree) to 6 (strongly agree). The questionnaires were distributed (both offline and online) to 21 individuals working for organisations that have previously focused on sustainability, at least at the managerial level. After processing the results of the survey questionnaires using SmartPLS software, the sustainability maturity domains as well as their sub-domains were verified. The next step in designing the CSMM was identifying the critical requirements and formulating the indicators (as assessment rubrics for each maturity level) in order to develop the initial CSMM.

\section{Scoping the previous works of maturity models}

As mentioned in the research methodology section, a systematic literature review was performed to scope the existing maturity models. By using specific search criteria, this literature review produced 33 relevant articles out of the 406 articles. According to Table 3, which presents the distribution of developed maturity models among the 33 selected articles, the number of articles increased from 4 to 12 between 2013 and 2015. In the early 1970s, Richard L. Nolan developed the Stages of Growth Model to map the maturity of information technology applications in business organisations. This was followed by Watts Humphrey's Capability Maturity Model that assessed and improved software development processes in the 1980s. Since then, such assessments have been applied in different subject areas. For example, Macchi and Fumagalli (2013) proposed a maintenance maturity assessment, 


\begin{tabular}{|c|c|c|c|c|}
\hline $\begin{array}{l}\text { Reference (sorted by } \\
\text { year) }\end{array}$ & $\begin{array}{l}\text { Year (\# of } \\
\text { articles) }\end{array}$ & Maturity model & Relevance* & \multirow{4}{*}{$\begin{array}{r}\text { Corporate } \\
\text { sustainability } \\
\text { maturity model }\end{array}$} \\
\hline Okongwu et al. (2013) & \multirow[t]{3}{*}{$2013(4)$} & Maturity of Supply Chain Sustainability Disclosure & \multirow[t]{4}{*}{$v$} & \\
\hline $\begin{array}{l}\text { Macchi and Fumagalli } \\
\text { (2013) }\end{array}$ & & Maintenance Maturity Assessment & & \\
\hline Killen and Hunt (2013) & & $\begin{array}{l}\text { Outcomes and Learning-based Maturity Model (for } \\
\text { Project Portfolio Management) }\end{array}$ & & \\
\hline Xiaofen (2013) & & Enterprise Quality Management Maturity Model & & \\
\hline Edgeman and & \multirow[t]{8}{*}{$2014(7)$} & Sustainability Enterprise Excellence Resilience and & \multirow[t]{20}{*}{$v$} & \\
\hline Williams (2014) & & Robustness Maturity Assessment & & \\
\hline $\begin{array}{l}\text { Brookes et al. (2014) } \\
\text { Hartono et al. (2014) }\end{array}$ & & Project Management Maturity Model & & \\
\hline $\begin{array}{l}\text { Hartono et al. (2014) } \\
\text { Islam and Brousseau }\end{array}$ & & Project Risk Management Maturity & & \\
\hline $\begin{array}{l}\text { Islam and Brousseau } \\
\text { (2014) }\end{array}$ & & Technology Maturity Assessment & & \\
\hline Jin et al. (2014) & & New Service Development Maturity Model & & \\
\hline Oliva (2014) & & Knowledge Management Maturity Model & & \\
\hline $\begin{array}{l}\text { Alencar Rigon et al. } \\
\text { (2014) }\end{array}$ & & Information Security Maturity & & \\
\hline Alvarez et al. (2015) & \multirow[t]{12}{*}{$2015(12)$} & Servitisation Maturity Model & & \\
\hline Backlund et al. (2015) & & Project Management Maturity Model & & \\
\hline $\begin{array}{l}\text { Benmoussa et al. } \\
\text { (2015) }\end{array}$ & & Capability Maturity Model Integration & & \\
\hline $\begin{array}{l}\text { Carroll and Helfert } \\
\text { (2015) }\end{array}$ & & Service Capability Sourcing Model & & \\
\hline de Boer et al. (2015) & & Business Process Management Maturity Model & & \\
\hline $\begin{array}{l}\text { Huang and Handfield } \\
\text { (2015) }\end{array}$ & & Supply Chain Maturity Model & & \\
\hline van Lith et al. (2015) & & Purchasing Maturity Model & & \\
\hline Pekkola et al. (2015) & & Reflective Practices & & \\
\hline Rendon (2015) & & Contract Management Maturity Model & & \\
\hline Secundo et al. (2015) & & Intellectual Capital Maturity Model & & \\
\hline Souza et al. (2015) & & Supply Chain Process Management Maturity Model & & \\
\hline Wilson (2015) & & Quality Maturity Model & & \\
\hline $\begin{array}{l}\text { Terouhid and Ries } \\
\text { (2016) }\end{array}$ & \multirow[t]{7}{*}{$2016(8)$} & $\begin{array}{l}\text { Framework for Organisational Sustainability } \\
\text { Excellence }\end{array}$ & \multirow[t]{7}{*}{$v$} & \\
\hline $\begin{array}{l}\text { Comuzzi and Patel } \\
\text { (2016) }\end{array}$ & & Big Data Maturity Model & & \\
\hline Dyerson et al. (2016) & & Information Technology Readiness for Small Firms & & \\
\hline Katuu (2016) & & Enterprise Content Management Maturity Model & & \\
\hline $\begin{array}{l}\text { Ramadan and Arafeh } \\
\text { (2016) }\end{array}$ & & Healthcare Quality Maturity Assessment Model & & \\
\hline Secundo et al. (2016) & & Technology Transfer Efficiency & & \\
\hline AlShathry (2016) & & $\begin{array}{l}\text { Business Process Management Maturity } \\
\text { Assessment }\end{array}$ & & \\
\hline Tontini et al. (2016) & \multirow[b]{2}{*}{2017 (2) } & Procurement and Supply Management & \multirow{3}{*}{$v$} & \\
\hline $\begin{array}{l}\text { Parker et al. (2017) } \\
\text { Alach (2017) }\end{array}$ & & $\begin{array}{l}\text { Operations Sustainability Maturity Model } \\
\text { A Seven-element Maturity Model of Performance } \\
\text { Measurement }\end{array}$ & & $\begin{array}{r}\text { Distribution of } \\
\text { developed maturity }\end{array}$ \\
\hline \multicolumn{3}{|c|}{ Note(s): * Relevance: the model is related to the subject of interest, i.e. sustainability } & & $\begin{array}{l}\text { selected articles } \\
\text { selis }\end{array}$ \\
\hline
\end{tabular}

Xiaofen (2013) described how the quality management maturity level can be investigated, Jin et al. (2014) devised a new service development maturity model and Rendon (2015) assessed the maturity of the contract management process. Meanwhile, in the last 2 years, the paradigm of maturity model development started to shift from model development for specific business processes to more complicated systems such as the Enterprise Content 
Management Maturity Model (Katuu, 2016), the Business Process Management Maturity Assessment (AlShathry, 2016), the Big Data Maturity Model (Comuzzi and Patel, 2016), Information Technology Readiness (Dyerson et al., 2016), technology transfer (Secundo et al., 2016) and sustainability maturity (Terouhid and Ries, 2016; Parker et al., 2017).

However, among the 33 selected articles, only four maturity models were related to sustainability maturity or sustainability assessment. Table 4 compares the sustainability maturity models found in the literature review, including the maturity domains and levels in each model. As far as the development method and objectives are concerned, three out of the four models were developed using a combination of qualitative and quantitative development methods. First, Parker et al. (2017) conducted a literature review and structured interviews with experts in order to develop a sustainability maturity model that could compare the

\begin{tabular}{llll}
\hline Reference & Industry & Maturity domains & Maturity levels \\
\hline $\begin{array}{lll}\text { Okongwu } \\
\text { et al. (2013) }\end{array}$ & $\begin{array}{l}\text { 50 organisations } \\
\text { (sustainability } \\
\text { reports) }\end{array}$ & $\begin{array}{l}\text { Seven elements of maturity: (1) } \\
\text { stakeholders; (2) governance; (3) } \\
\text { supply chain operations; (4) }\end{array}$ & $\begin{array}{l}\text { Three maturity levels of } \\
\text { maturity are used: (1) define and } \\
\text { report; (2) measure and manage } \\
\text { and (3) improve and change. For }\end{array}$ \\
& societal development & supply chain sustainability, \\
& sustainability; (5) supply chain & (6) TBL & there are four levels: Initial, \\
& performance and (7) international & intermediate, advanced and \\
& standards & world class
\end{tabular}

Parker et al. Financial Services

(2017)

Organisations

Edgeman and General Williams

(2014)

Terouhid and Ries (2016)

Table 4.

Comparison of the existing sustainability maturity models
Supply chain sustainability elements include the following: Use of standards, performance management, life cycle management, pollution management, relation management, employee management, profitability management and economic value Five domains: corporate sustainability, economic capital, societal capital, human capital and natural capital

Six levels: (1) triple top-line strategy and governance; (2) process implementation, translation and execution; (3) financial and marketplace performance; (4) sustainable enterprise excellence, resilience and robustness embedded in the economic, innovation and analytic impact; (5) human ecology and capital performance and (6) social-ecological innovation and general innovation, design and continuous improvement performance

Capability areas include: leadership, policy and strategy, people, partnership and process
Five levels: willingness to change, desire to change, ready for a change, systematic change and corporate culture

Five levels: very low maturity (low awareness), low maturity (sporadic/reactive), moderate maturity (early systematic approaches), high maturity (aligned and partially integrated) and very high maturity (deeply integrated into the culture)

Five levels: inactive non compliance, basic compliance, beyond compliance, integrated sustainability and sustainable leadership 
financial organisations between developed and developing countries. Second, Terouhid and Ries (2016) performed a literature review to design a conceptual model of organisational sustainability excellence for construction firms. They also used the European Foundation for Quality Management and interviewed experts in order to develop and validate the model. Third, Okongwu et al. (2013) derived the maturity elements of supply chain sustainability from a literature review, conducted principal component analysis to identify the interconnections among the elements and assessed maturity levels, based on a content analysis of 50 sustainability reports distributed in 10 different industrial sectors. Conversely, Edgeman and Williams (2014) used a quantitative approach to develop their model, which was not implemented in any specific industry. More specifically, they adapted the springboard approach in their Sustainability Enterprise Excellence Model and applied the concepts of resilience and robustness in order to assess the health of an organisation.

As stated earlier, none of the four maturity models obtained from the scoping phase offered an organisational assessment scheme for implementing corporate sustainability. The maturity model developed in this study, called the CSMM, will be used by organisations as a self-assessment tool. Technically, the CSMM will be designed in the form of a matrix that maps organisational capabilities in various domains of corporate sustainability with different levels of maturity. Through this CSMM, organisations can determine the current level of readiness and help organisations to increase their level of maturity towards an ideal sustainable organisation. The development of maturity models generally uses a qualitative approach. The development of the CSMM in this study will use qualitative and quantitative methods not only to design models but also to verify them for various experts or practitioners and evaluate the feasibility of implementing the model in the context of local content and adaptability of the model for practical use. The CSMM, developed in this study, can be said to be the first sustainability maturity model developed in an Indonesian context. The result might probably illustrate the phenomenon of corporate sustainability implementation in developing countries.

\section{Designing the CSMM}

The proposed CSMM is a maturity model that uses a matrix-type approach (Figure 2) in which the matrix is based on the maturity domains and levels. In this matrix, there is a set of indicators (along with their capability processes) that determines the criteria for each maturity level. Meeting these criteria will make the organisation eligible to move on to the next level of maturity.

\subsection{Formulating the maturity domains and sub-domains}

On the basis of the systematic literature review, the content analysis and the expert interviews, a maturity domain framework for the CSMM was obtained. This framework was also based on Epstein's Corporate Sustainability Model (Epstein and Buhovac, 2008) and Blackburn's Sustainable Operating System (Blackburn, 2007).

\begin{tabular}{|c|c|c|c|c|}
\hline \multirow{2}{*}{ Maturity Model } & \multirow{2}{*}{$\begin{array}{l}\text { The Description of } \\
\text { Capability/Process }\end{array}$} & \multicolumn{3}{|c|}{ Maturity Level } \\
\hline & & Level 1 & Level 2 & Level 3 \\
\hline \multirow{2}{*}{ Maturity Domain 1} & Maturity Sub-domain A & $\begin{array}{l}\text { Rubrics \& } \\
\text { Indicators }\end{array}$ & $\begin{array}{l}\text { Rubrics \& } \\
\text { Indicators }\end{array}$ & $\begin{array}{l}\text { Rubrics \& } \\
\text { Indicators }\end{array}$ \\
\hline & Maturity Sub-domain B & $\begin{array}{l}\text { Rubrics \& } \\
\text { Indicators }\end{array}$ & $\begin{array}{l}\text { Rubrics \& } \\
\text { Indicators }\end{array}$ & $\begin{array}{l}\text { Rubrics \& } \\
\text { Indicators }\end{array}$ \\
\hline \multirow{2}{*}{ Maturity Domain 2} & Maturity Sub-domain C & $\begin{array}{l}\text { Rubrics \& } \\
\text { Indicators }\end{array}$ & $\begin{array}{l}\text { Rubrics \& } \\
\text { Indicators }\end{array}$ & $\begin{array}{l}\text { Rubrics \& } \\
\text { Indicators }\end{array}$ \\
\hline & Maturity Sub-domain D & $\begin{array}{l}\text { Rubrics \& } \\
\text { Indicators }\end{array}$ & $\begin{array}{l}\text { Rubrics \& } \\
\text { Indicators }\end{array}$ & $\begin{array}{l}\text { Rubrics \& } \\
\text { Indicators }\end{array}$ \\
\hline
\end{tabular}

Figure 2. A matrix-type maturity model (self-made) sustainability maturity model 
In this model, there are enabling factors that place pressure (both external and internal) on organisations to implement and carry out sustainability activities. These factors become the inputs for the corporate sustainability strategy domain, after which the organisation processes these inputs and formulates a strategy. Subsequently, the organisation puts the strategy into action and obtains economic, environmental and social benefits, all of which are used to measure corporate sustainability performance. The proposed CSMM includes six maturity domains and 29 sub-domains (see Table 5).

\subsection{Verifying the maturity domains and sub-domains}

The process of verifying the CSMM included structured survey questionnaires and quantitative analysis using PLS-SEM and SmartPLS software. As stated earlier, this model consists of six maturity domains (hereafter referred to as the latent variables) and 29 maturity sub-domains (hereafter referred to as the indicators).

The survey questionnaires involved 21 organisations with the following profiles:

(1) The industry sector: manufacturers $(64 \%)$, distributors $(23 \%)$ and those from food and beverages, logistics and insurance $(4.7 \%)$.

(2) $62 \%$ were large-scale enterprises (>100 employees), $33 \%$ were medium-scale enterprises and $5 \%$ were small-scale enterprises ( $<20$ employees).

\begin{tabular}{|c|c|c|}
\hline \multirow{2}{*}{$\frac{\text { Six maturity domains }}{\text { CS driver (external) }}$} & \multicolumn{2}{|c|}{ Maturity sub-domains } \\
\hline & EP1 & Compliance with government and institutional regulations \\
\hline & $\mathrm{EP} 2$ & Place of marketing for products/services produced \\
\hline & EP3 & Market demand for greener products/services \\
\hline & EP4 & Demands or pressure from external stakeholders \\
\hline & EP5 & Support from the realisation of a government programme \\
\hline & EP6 & Availability of information related to raw materials \\
\hline \multirow[t]{12}{*}{ CS driver (internal) } & IP1 & Idea/demand for a change from the management towards the sustainability \\
\hline & IP2 & The seriousness of an organisation to carry out sustainability \\
\hline & IP3 & The risk of the goods produced \\
\hline & IP4 & Supporting the capacity of human resources \\
\hline & IP5 & Fund availability/allocation \\
\hline & IP6 & The risk management of products/services \\
\hline & IP7 & Philosophy/values adopted by the organisation \\
\hline & IP8 & Appeal/benefits for internal stakeholders \\
\hline & IP9 & Awareness of being responsible for environmental conservation \\
\hline & IP10 & Standard of ethics and work cultures \\
\hline & IP11 & Goals to be achieved by the organisation \\
\hline & IP12 & Reputation/image to be built by the organisation \\
\hline \multirow[t]{4}{*}{ CS strategy } & CSS1 & Leader's commitment to realising the vision and mission \\
\hline & CSS2 & $\begin{array}{l}\text { Leader's competence to integrate sustainability into the organisation's } \\
\text { strategy }\end{array}$ \\
\hline & CSS3 & To adjust the organisational structure and the applied strategy \\
\hline & CSS4 & The policy made by top management to execute the strategy \\
\hline \multirow{4}{*}{ CS action } & CSA1 & Corporate Philanthropy \\
\hline & CSA2 & Corporate Social Responsibility \\
\hline & CSA3 & Corporate Sustainable Management \\
\hline & CSA4 & Sustainable Entrepreneurship \\
\hline \multirow[t]{3}{*}{ CS performance } & CSP1 & Economic benefit \\
\hline & CSP2 & Environmental benefit \\
\hline & CSP3 & Social benefit \\
\hline
\end{tabular}

Table 5.

Description of the proposed CSMM: Maturity domains and sub-domains 
(3) $57 \%$ had national coverage of marketing, $24 \%$ had international coverage and $19 \%$ had regional coverage.

(4) $48 \%$ were public companies/plcs.

(5) $48 \%$ had a corporate sustainability strategy.

(6) $48 \%$ produced sustainability reports.

The analysis of the proposed CSMM (as shown in Figure 3) consisted of two stages: (1) a measurement model analysis, i.e. an analysis of the outer model, including the relationship between the latent variables and their indicators; and (2) a structural model analysis, i.e. an analysis of the inner model, including the relationship between the latent variables. The reason for these two stages was that it must be ensured that the relationship between the latent variables and their indicators (i.e. the measurement model) meets the standard limits in order for the relationship between the latent variables (i.e. the structural model) to provide valid results.

Moreover, the measurement model analysis was achieved by testing convergent and discriminant validity. Convergent validity determines whether a set of indicators effectively represent the latent variables (Sarwono and Narimawati, 2015), which is achieved by examining the outer loading value, the $p$-value, the average variant extracted (AVE) value and composite reliability. It also includes the following requirements: an outer loading value of at least 0.4 ; a $p$-value $<\alpha=0.05$; 0.50 for the AVE value and 0.70 for composite reliability (Sholihin and Ratmono, 2013; Woo et al., 2013). The indicators that do not meet these requirements are extracted in the subsequent analysis. According to the convergent validity test results in Table 6, the AVE value was below the minimum standard, and through several iterations, six indicators were discarded in the analysis (IP5, IP8, IP9, IP10, IP11 and IP12).

Discriminant validity determines whether two different variables show adequate differences (Sarwono and Narimawati, 2015). In this case, the loading value is the loading value of the indicator of the latent variable itself, whereas the cross-loading value is the loading value of the indicator of other latent variables. If the indicator includes a crossloading value that is higher than the loading value, then the indicator must be extracted from the latent variable. On the basis of the discriminant validity test results, two indicators must be discarded, i.e. EP4 and CSS3, since their cross-loading values were higher than the loading value.

In the analysis of the structural models, testing was conducted to determine whether the relationship between the latent variables was significant. This was achieved through bootstrapping, which focuses on the relationship between the $p$-values and the latent variables in the model. In this regard, the following hypotheses are posited:
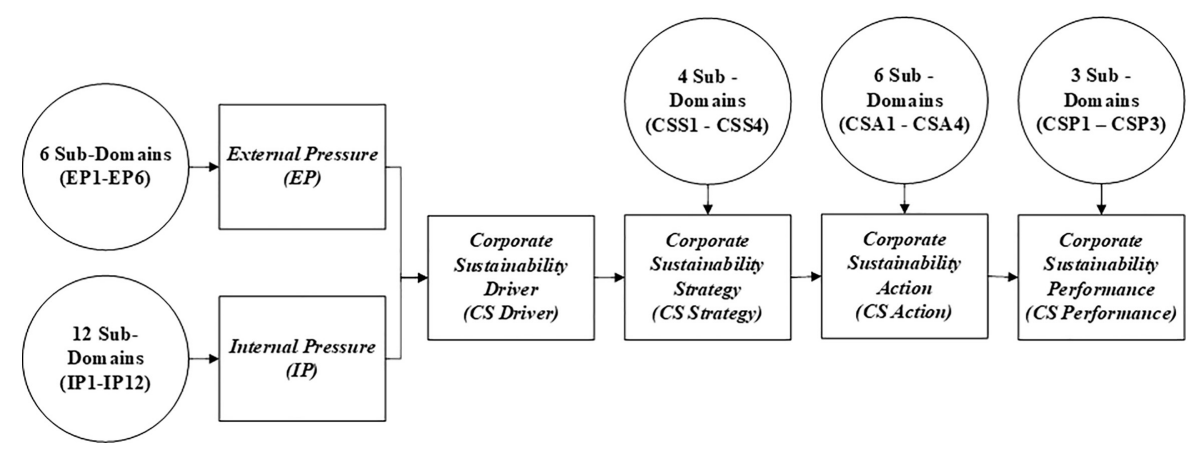
maturity model

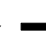




\section{IJPPM}

\begin{tabular}{|c|c|c|c|c|c|}
\hline Latent variable & $\begin{array}{l}\text { Composite } \\
\text { reliability }\end{array}$ & $\begin{array}{c}\text { Average } \\
\text { variant } \\
\text { extracted }\end{array}$ & $\begin{array}{l}\text { Number of } \\
\text { indicators }\end{array}$ & $\begin{array}{l}\text { Outer loading } \\
\text { (min; } \max )\end{array}$ & $\begin{array}{l}\text { Significance } \\
\text { (min; max) }\end{array}$ \\
\hline \multicolumn{6}{|l|}{ Convergent validity } \\
\hline CS Action (CSA) & 0.832 & 0.566 & 6 & $(0.588 ; 0.800)$ & $(0.000 ; 0.001)$ \\
\hline $\begin{array}{l}\text { CS Performance } \\
\text { (CSP) }\end{array}$ & 0.845 & 0.660 & 12 & $(0.429 ; 0.725)$ & $(0.000 ; 0.011)$ \\
\hline $\begin{array}{l}\text { CS Strategy } \\
\text { (CSS) }\end{array}$ & 0.869 & 0.627 & 4 & $(0.667 ; 0.855)$ & $(0.000 ; 0.000)$ \\
\hline $\begin{array}{l}\text { External } \\
\text { Pressure (EP) }\end{array}$ & 0.874 & 0.538 & 4 & $(0.502 ; 0.907)$ & $(0.000 ; 0.004)$ \\
\hline $\begin{array}{l}\text { Internal } \\
\text { Pressure (IP) }\end{array}$ & 0.864 & $0.362^{*}$ & 3 & $(0.497 ; 0.966)$ & $(0.000 ; 0.033)$ \\
\hline \multicolumn{6}{|c|}{ Discriminant validity } \\
\hline $\begin{array}{l}\text { External } \\
\text { Pressure } \\
\text { EP4 }\end{array}$ & \multicolumn{5}{|c|}{ and the cross-loading factor of EP4 on IP $=0.825$} \\
\hline $\begin{array}{l}\text { CS Strategy } \\
\text { CSS3 }\end{array}$ & \multicolumn{5}{|c|}{$\begin{array}{l}\text { The loading factor of } \operatorname{CSS} 3 \text { on CSS }=0.659 \text {. The cross-loading factor of } \operatorname{CSS} 3 \text { on } \\
\mathrm{CSP}=0.667 \text {, and the cross-loading factor of } \mathrm{CSS} 3 \text { on } \mathrm{EP}=0.676\end{array}$} \\
\hline \multicolumn{6}{|c|}{ Note(s): $*$ The value is lower than the minimum standard } \\
\hline
\end{tabular}

\section{Table 6.}

Convergent and discriminant validity tests of the outer mode
HO. There is no significant effect between the latent variables.

H1. The External Pressure variable has a significant effect on the CS Driver variable.

H2. The Internal Pressure variable has a significant effect on the CS Driver variable.

H3. The CS Driver variable has a significant effect on the CS Strategy variable.

H4. The CS Strategy variable has a significant influence on the CS Action variable.

H5. The CS Action variable has a significant effect on the CS Performance variable.

H6. The CS Driver variable has a significant effect on the CS Action variable.

The decision to reject $\mathrm{H} 0$ is made if the $p$-value is less than $\propto=0.05$. Bootstrapping was also performed, the results of which are shown in Table 7.

On the basis of the results in Table 7, H1, H2, H3 and $\mathrm{H} 5$ were significant, whereas the relationship between the CS Strategy variable and the CS Action variable (H4) was not significant. Thus, a modification of the initial model was made (Figure 4), by adding the relationship between the CS Driver variable directly to the CS Action variable (H6). This was also based on the findings that Indonesian companies tend to conduct sustainability efforts without having a CS Strategy in place.

\begin{tabular}{llcccc}
\hline & Relationship between the latent & \multicolumn{2}{c}{ Base model } & \multicolumn{2}{c}{ Modified model } \\
Hypotheses & variables & p-value & Test result & p-value & Test result \\
\hline H1 & External Pressure $\rightarrow$ CS Driver & 0.000 & Significant & 0.000 & Significant \\
H2 & Internal Pressure $\rightarrow$ CS Driver & 0.000 & Significant & 0.000 & Significant \\
H3 & CS Driver $\rightarrow$ CS Strategy & 0.000 & Significant & 0.000 & Significant \\
H4 & CS Strategy $\rightarrow$ CS Action & 0.991 & Not & 0.299 & Not \\
& & & significant & & significant \\
& CS Action $\rightarrow$ CS Performance & 0.000 & Significant & 0.000 & Significant \\
H6 & CS Driver $\rightarrow$ CS Action & - & - & 0.031 & Significant \\
H6 & & & & &
\end{tabular}

Table 7.

Results of the inner model analysis 

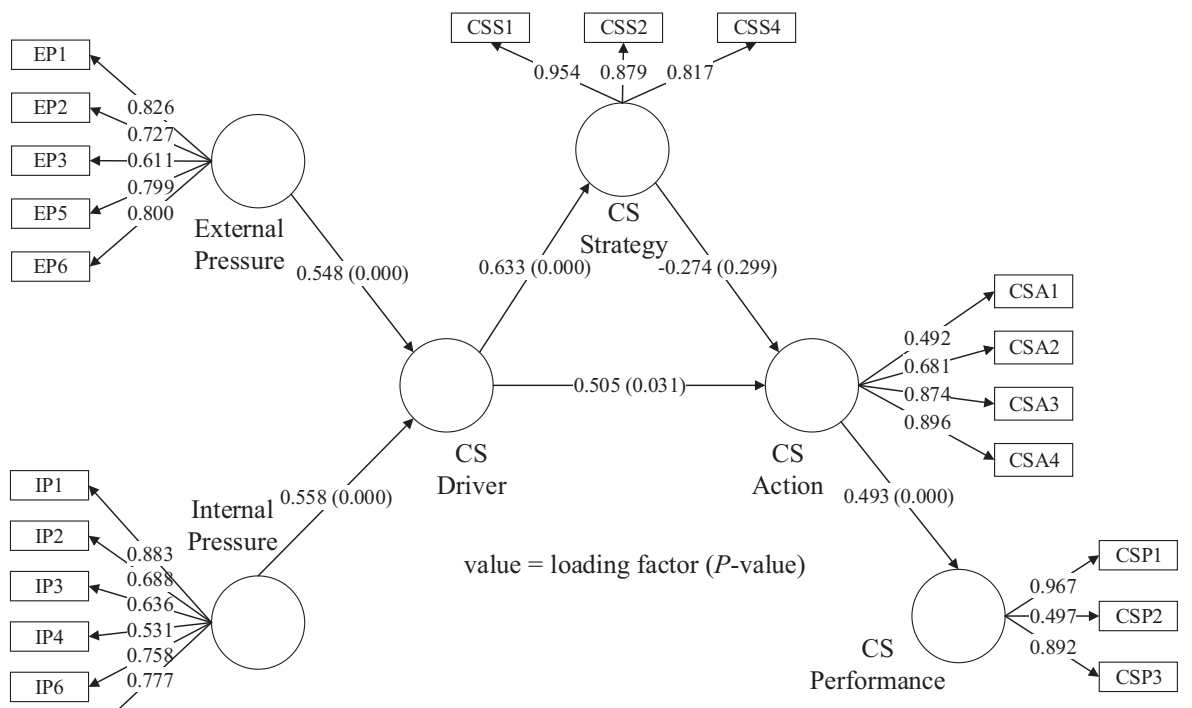

IP7

Moreover, the relationship between the CS Strategy variable and the CS Action variable was insignificant, whereas the relationship between the CS Driver variable and the CS Action variable was significant. This indicates that the CS Strategy variable does not have any significant influence on the implementation of sustainability activities. This also shows that the indicators that compile the CS Strategy variable, such as the commitment of leaders in realising the vision and mission (CSS1), the ability of leaders to integrate sustainability into the organisational strategy (CSS2), aligning the organisational structure with the implemented strategies (CSS3) and the existence of policies formed by top management to oversee the implementation of such strategies (CSS3), do not have a significant influence on sustainability efforts. In other words, without these factors, the organisation can still conduct such activities. Finally, on the basis of the aforementioned results, the presence of external and internal pressure (the CS Driver variable) is the main factor that drives an organisation to carry out sustainability efforts (the CS Action variable).

\subsection{Maturity levels}

Although maturity levels tend to range from three to six levels (Jin et al., 2014), the results of the scoping stage (see Table 8) indicated that the maturity models were generally classified into five maturity levels. Although the definitions of these five maturity levels have evolved over time, the original definitions are presented as follows (Paulk et al., 1995):

Level 1 - The initial stage: Processes that are unpredictable, poorly controlled and reactive. These are organisations in which the processes are ad hoc, with no planning.

Level 2 - The managed stage: Processes that are often reactive. These are organisations in which some macro processes are mapped and executed, with some degree of consistency. However, many processes remain uncontrolled.

Level 3 - The defined stage: Processes that are often proactive. These are organisations in which all basic processes are defined, with some degree of control. They are also concerned about storing data and using indicators. 


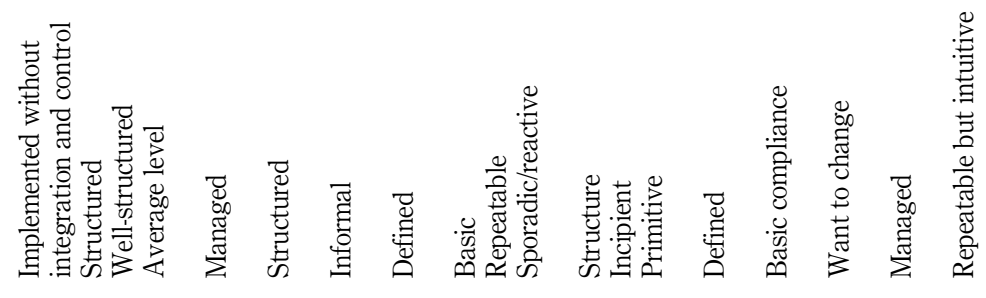

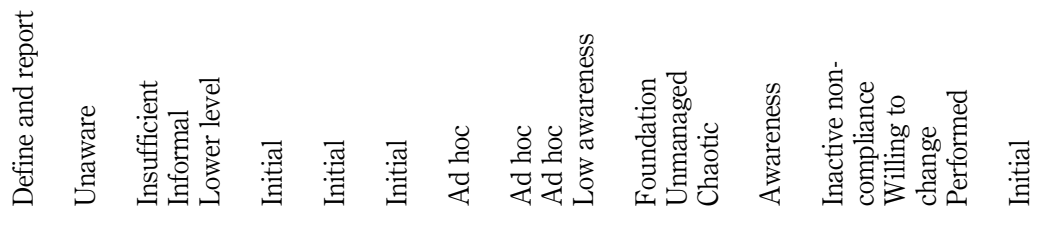

Table 8.

Comparison of the different maturity levels

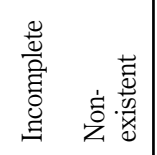

$m \pi$ H

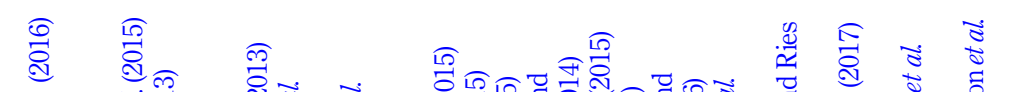

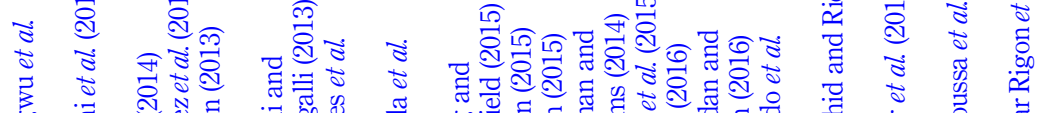

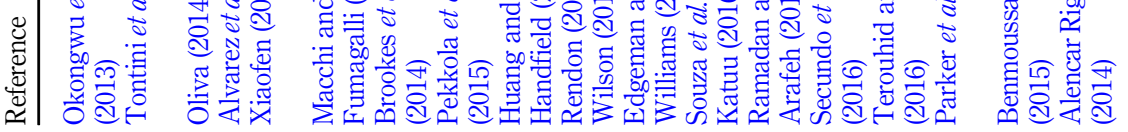


Level 4 - The quantitatively managed stage: Processes that are measured and controlled. These organisations apply process management in which consistent information is stored. They also use indicators to monitor processes and achieve the established goals.

Level 5 - The optimised stage: The main focus is on process improvement. These organisations not only provide training on processes for their staff members but also are involved in their improvement.

Although many researchers tend to use five maturity levels, there are those who prefer an even number of levels. For example, Alencar Rigon et al. (2014) and Benmoussa et al. (2015) used up to six levels, whereas Oliva (2014); Alvarez et al. (2015) and Okongwu et al. (2013) used up to four levels. More levels are chosen to explain more specifically a certain level of maturity or a smaller number of maturity levels are formulated by combining several similar maturity levels into one. In the present study, the proposed CSMM includes three maturity levels. This is due to the consideration of organisations to facilitate them in classifying organisational achievements in the most ideal conditions (level 3), the most primitive conditions (level 2) or conditions in between (level 2). For the conditions of low awareness of corporate sustainability implementation, the usage of three levels becomes a solution to map the levels in such a way that the capabilities between levels are mutually exclusive and easy to be distinguished.

\subsection{The proposed CSMM}

On the basis of the validation results, the proposed CSMM (Table 9) will map those maturity domains within three maturity levels. The final step is to prepare the relevant indicators that can be tracked through a literature review and evaluated by practitioners. The three maturity levels are defined as follows:

Level 1 - The initial stage: Immature organisations in which the processes are undefined and applied on an ad hoc basis.

Level 2 - The managed stage: Organisations in which process management is weak, because of organisational deficiencies. Although the processes are defined and some standards are established, some indicators are determined but not measured.

Level 3 - The optimised stage: Mature organisations in which process management is applied to measure organisational performance and to evaluate process improvement efforts/programmes.

\section{Discussion and implications}

The placing of Indonesia in the bottom 12 (out of 65 countries), the fact proposed by RobecoSAM's Corporate Sustainability Assessment per October 2017, raised the initial hypothesis of whether it is associated with the low awareness of corporate sustainability implementation in the country as a whole. Based on the examination of sustainability reports, several noteworthy premises can be made. First, after examining approximately 50 sustainability reports produced by Indonesian organisations from 2010 to 2017, the majority of the organisations have mistakenly considered corporate social responsibility programmes as corporate sustainability deeds, both in the form of community development programmes and philanthropic activities. Second, after probing sustainability reports from 2005 to 2013, the industry sectors of Indonesian organisations, which had participated in developing the sustainability reports, were extending from the organisations in exploring natural resources to those in the infrastructure, consumer goods, banking, electronics and property sectors. 


\begin{tabular}{lllll}
\hline & & & Maturity level 2: & \\
Maturity domains & $\begin{array}{l}\text { Relevant } \\
\text { indicators }\end{array}$ & Maturity level 1: & $\begin{array}{l}\text { The managed } \\
\text { The initial stage }\end{array}$ & Mage \\
\hline
\end{tabular}

Corporate sustainability driver

Anticipating the Availability of a external pressure national policy

of compliance with (Sharma and

government and institutional regulations

Anticipating the internal pressure from the management in the direction of sustainability

Balachandra, 2015)

Legal compliance

Rahdari and

Rostamy (2015); and Penalties for non-compliance Hervani et al. (2005).

Sustainability initiatives Tan et al. (2015);

Awareness among managers

Colicchia et al. (2013); and Return on investment Figge et al. (2004).

\section{Corporate sustainability action}

Programmes/ Activities

\section{Table 9.}

Funds donated to the community

Epstein and

Buhovac (2008)

Energy

productivity or total energy consumption

Rahdari and

Rostamy (2015)

Free hazardous materials or the usage of biodegradable packaging Lin et al. (2010); and Renewable energy usage policy Suwartha and Sari, (2013).
Regulations are not applied.

Compliance of organisations with regulations is reactive.

Anticipation is done when problems arise (e.g. receiving a reprimand) The management team only focuses on aspects of profit and have little-tono concern for sustainability issues, knowledge or practices

There are no dedicated resources to implement any process of corporate sustainability

Corporate sustainability activities in the form of philanthropic activities (e.g. donations/ contributions do not have a direct relationship with business activities)
Policies and regulations are identified. The organisation includes defined processes related to fulfilling regulatory compliance

The management team has a better acquaintance of sustainability, knowledge and practices Sporadic efforts and some resources are dedicated (e.g. to raise awareness or establish standards)

Activities that
arise from
stakeholders'
demands, which
lead to cooperation
with stakeholders
(e.g. corporate
social
responsibility
programmes)
Activities are also
related to efforts to
resolve
sustainability
issues that arise
from the core
business (e.g.
waste
management and
energy efficiency)

Organisations are involved in the associations (in their industry), which play active roles in the formulation of regulations

The management team incorporates initiatives related to corporate sustainability into the formulation of a strategy More resources are dedicated to improving the implementation of corporate sustainability

Proactive and mature sustainability efforts, in which organisations integrate sustainability into their strategies and business goals This activity will provide benefits to companies related to the top financial line (e.g. process and product innovation using green technology)

(continued) 


\begin{tabular}{|c|c|c|c|c|c|}
\hline Maturity domains & $\begin{array}{l}\text { Relevant } \\
\text { indicators }\end{array}$ & $\begin{array}{l}\text { Maturity level 1: } \\
\text { The initial stage }\end{array}$ & $\begin{array}{l}\text { Maturity level } 2 \text { : } \\
\text { The managed } \\
\text { stage }\end{array}$ & $\begin{array}{l}\text { Maturity level 3: } \\
\text { The optimised stage }\end{array}$ & maturity model \\
\hline $\begin{array}{l}\text { Corporate sustainabi } \\
\text { Economic, Social or } \\
\text { Environmental } \\
\text { Benefits }\end{array}$ & $\begin{array}{l}\text { ity performance } \\
\text { Operating or net } \\
\text { profit Feil et al. } \\
\text { (2015) } \\
\text { Emission of toxic } \\
\text { substances into the } \\
\text { air, water and soil } \\
\text { Jasinski et al. (2016) } \\
\text { Increase } \\
\text { employment } \\
\text { opportunities for } \\
\text { the local } \\
\text { community Lin } \\
\text { et al. }(2010)\end{array}$ & $\begin{array}{l}\text { Sustainability } \\
\text { indicators are } \\
\text { defined, but they } \\
\text { only cover one } \\
\text { dimension of } \\
\text { sustainability } \\
\text { benefits (usually } \\
\text { economic benefits) } \\
\text { There is } \\
\text { infrequent } \\
\text { monitoring with } \\
\text { no actions taken }\end{array}$ & $\begin{array}{l}\text { A range of } \\
\text { sustainability } \\
\text { indicators } \\
\text { covering two } \\
\text { dimensions of } \\
\text { sustainability } \\
\text { benefits. They are } \\
\text { defined and } \\
\text { measured, but the } \\
\text { metrics are not } \\
\text { fully aligned with } \\
\text { business goals } \\
\text { Some corrective } \\
\text { actions are taken }\end{array}$ & $\begin{array}{l}\text { Balanced } \\
\text { sustainability } \\
\text { indicators, including } \\
\text { economic, social and } \\
\text { environmental } \\
\text { benefits, are defined } \\
\text { and measured. The } \\
\text { metrics are fully } \\
\text { aligned with } \\
\text { business goals } \\
\text { Actions are taken to } \\
\text { ensure that the } \\
\text { organisations } \\
\text { achieve their } \\
\text { business goals }\end{array}$ & Table 9. \\
\hline
\end{tabular}

Third, several Indonesian companies utilised comprehensive approaches and strategic frameworks that not only integrated sustainability strategies into their business processes but also synergised environmental alignment and community empowerment activities in order to achieve organisational profits. However, these mature organisations have not involved themselves in producing sustainability reports or conducting sustainability assessments. On the basis of these, the initial hypothesis was defined as follows: many Indonesian organisations are not fully aware of the importance of sustainability benefit.

The result of statistical testing based on PLS-SEM has supported the initial hypothesis. It is important to note some interesting findings based on the 21 Indonesian organisations in this study. First, there are some organisations that conduct sustainability programmes/ activities, without actually having a strategic plan that is aligned with their organisational goals. Second, the majority of the organisations have conducted sustainability efforts, due to both internal and external pressure. Third, the factors driving organisations to conduct corporate sustainability generally depend on the leadership. Finally, although various factors, such as organisational reputation gained from implementing corporate sustainability, attractiveness to employee recruitment and awareness of environmental sustainability, seem relevant in this era of globalisation, they were insignificant for Indonesian organisations.

The practical implication of model verification based on PLS-SEM indicated that organisations have a tendency to execute sustainability programmes independently from how organisations anticipate external and internal pressures and translate them into corporate strategy management. To achieve the ideal model, the organisations need to improve themselves; they are required to be able to translate the organisation's external and internal pressures into harmonious sustainability activities as well as optimising the organisation's strategies so that programmes and indicators are aligned to achieve organisational goals. Not only indicators measured in various dimensions of triple bottom line and many sustainability programmes are run, but all of them are probably only for the purpose of exposure without getting the real benefits of implementing corporate sustainability.

The final result of this research, i.e. the design of the CSMM itself, will be able to provide theoretical and practical implications. Theoretically, the existing corporate sustainability 
models that define causal relationships start from anticipating corporate sustainability drivers and move towards formulating strategies and programmes, as well as measuring the sustainability performance, have been improved into a corporate sustainability maturity model. The proposed maturity model is detailed in various sub-domains that have been scientifically verified, having clearly defined indicators and rubric capabilities at each maturity level. In practical terms, the CSMM is offered as a self-assessment readiness tool and becomes more concrete to be used rather than becoming a paradox of a conceptual framework. The CSMM makes it easy for organisations to determine directions and strategies when they are at a certain maturity level and want to move to a better maturity level because the targeted capabilities are clearly defined.

\section{Conclusions and future recommendations}

The proposed CSMM in this study was developed by using a three-step development strategy (i.e. scoping, designing and evaluating). It also used a mixed-method approach that combined several qualitative and quantitative methods such as a systematic literature review, practitioner/expert interviews, content analysis, survey questionnaires and PLSSEM analysis. In addition, the domains, sub-domains and maturity levels in this model were not only obtained through a literature review of published scientific articles and sustainability reports from various organisations worldwide, but this particular maturity model was also verified and validated through practitioners' evaluations and the sustainability reports from various industries in Indonesia. Therefore, this CSMM can be claimed as the first sustainability maturity model developed for readiness assessment in an Indonesian context.

As far as generalisability is concerned, the use of systematic literature review in this study is limited to the Science Direct and Emerald databases. In future, the use of systematic literature review can be accelerated by using the bibliometrics method combined with the use of software so that it can provide benefits both in the quantum of selected scientific articles and time efficiency. The verification of the model was based on a limited number of organisations because of difficulties in finding organisations that have implemented corporate sustainability in Indonesia; however, it can be extended to the involvement of more organisations in Indonesia or to cross-country organisations for comparison purposes.

Another future recommendation is that further evaluation of this CSMM can include conducting practical maturity assessments in real-world organisations, particularly those in the same industries. This can also be useful for comparing the achievements of specific maturity domains as well as the benefits of benchmarking among various organisations. Other possible directions for future research can include the assessment process such as interviews and visits to various organisations as well as content analysis on sustainability documents can be improved through faster and more efficient assessment methods.

\section{References}

Adesola, S. and Baines, T. (2005), "Developing and evaluating a methodology for business process improvement", Business Process Management Journal, Vol. 11 No. 1, pp. 37-46.

Alach, Z. (2017), "Performance measurement maturity in a national set of universities", International Journal of Productivity and Performance Management, Vol. 66 No. 2, pp. 216-230.

Alencar Rigon, E., Merkle Westphall, C., Ricardo dos Santos, D. and Becker Westphall, C. (2014), “A cyclical evaluation model of information security maturity", Information Management and Computer Security, Vol. 22 No. 3, pp. 265-278.

AlShathry, O. (2016), "Business process management: a maturity assessment of Saudi Arabian organizations", Business Process Management Journal, Vol. 22 No. 3, pp. 507-521. 
Alvarez, R.L., Martins, M.R. and Silva, M.T. (2015), "Applying the maturity model concept to the servitization process of consumer durables companies in Brazil", Journal of Manufacturing Technology Management, Vol. 26 No. 8, pp. 1086-1106.

Aras, G., Aybars, A. and Kutlu, O. (2010), "Managing corporate performance: investigating the relationship between corporate social responsibility and financial performance in emerging markets", International Journal of Productivity and Performance Management, Vol. 59 No. 3, pp. 229-254.

Backlund, F., Chronéer, D. and Sundqvist, E. (2015), "Maturity assessment: towards continuous improvements for project-based organisations?”, International Journal of Managing Projects in Business, Vol. 8 No. 2, pp. 256-278.

Barclay, D.W., Higgins, C.A. and Thompson, R. (1995), "The partial least squares approach to causal modeling: personal computer adoption and use as illustration”, Technology Studies, Vol. 2, pp. 285-309.

Becker, J., Knackstedt, R. and Pöppelbuß, J. (2009), “Developing maturity models for IT management”, Business \& Information Systems Engineering, Vol. 1 No. 3, pp. 213-222.

Benmoussa, R., Abdelkabir, C., Abd, A. and Hassou, M. (2015), "Capability/maturity based model for logistics processes assessment: application to distribution processes", International Journal of Productivity and Performance Management, Vol. 64 No. 1, pp. 28-51.

Blackburn, W.R. (2007), Sustainability Handbook: The Complete Management Guide to Achieving Social, Economic, and Environmental Responsibility. Earthscan, Washington DC.

Brookes, N., Butler, M., Dey, P. and Clark, R. (2014), "The use of maturity models in improving project management performance: an empirical investigation", International Journal of Managing Projects in Business, Vol. 7 No. 2, pp. 231-246.

Carroll, N. and Helfert, M. (2015), "Service capabilities within open innovation: revisiting the applicability of capability maturity models", Journal of Enterprise Information Management, Vol. 28 No. 2, pp. 275-303.

Carroll, A.B. and Shabana, K.M. (2010), "The business case for corporate social responsibility: a review of concepts, research and practice", International Journal of Management Reviews, Vol. 12 No. 1, pp. 85-105.

Cerutti, O. and Gattino, B. (1992), Indicateurs et Tableaux De Bord, AFNOR, Paris.

Chin, W.W. and Newsted, P.R. (1999). "Structural equation modeling analysis with small samples using partial least squares", Statistical Strategies for Small Sample Research, Vol. 1 No. 1, pp. 307-341.

Colicchia, C., Marchet, G., Melacini, M. and Perotti, S. (2013), "Building environmental sustainability: empirical evidence from Logistics Service Providers", Journal of Cleaner Production, Vol. 59, pp. 197-209.

Comuzzi, M. and Patel, A. (2016), "How organisations leverage Big Data: a maturity model”, Industrial Management and Data Systems, Vol. 116 No. 8, pp. 1468-1492.

de Boer, F.G., Müller, C.J. and ten Caten, C.S. (2015), "Assessment model for organizational business process maturity with a focus on BPM governance practices", Business Process Management Journal, Vol. 21 No. 4, pp. 908-927.

De Bruin, T., Freeze, R., Kaulkarni, U. and Rosemann, M. (2005), "Understanding the main phases of developing a maturity assessment model", Australasian Conference on Information Systems (ACIS), 30 November - 2 December 2005, New South Wales, Sydney.

De Oliveira, O.J., Serra, J.R. and Salgado, M.H. (2010), “Does ISO 14001 work in Brazil?”, Journal of Cleaner Production, Vol. 18 No. 18, pp. 1797-1806.

Dyerson, R., Spinelli, R. and Harindranath, G. (2016), "Revisiting IT readiness: an approach for small firms", Industrial Management and Data Systems, Vol. 116 No. 3, pp. 546-563.

Dyllick, T. and Hockerts, K. (2002), "Beyond the business case for corporate sustainability", Business Strategy and the Environment, Vol. 11 No. 2, pp. 130-141. 
Edgeman, R. and Williams, J.A. (2014), "Enterprise self-assessment analytics for sustainability, resilience and robustness", The TQM Journal, Vol. 26 No. 4, pp. 368-381.

Elkington, J. (1997), Cannibals with Forks: The Triple Bottom Line of the 21st Century Business, New Society Publishers, Oxford.

Epstein, M.J. and Buhovac, A.R. (2008), Making Sustainability Work: Best Practices in Managing and Measuring Corporate Social, Environmental, and Economic Impacts, Greenleaf, Sheffield.

Feil, A.A., de Quevedo, D.M. and Schreiber, D. (2015), "Selection and identification of the indicators for quickly measuring sustainability in micro and small furniture industries", Sustainable Production and Consumption, Vol. 3, pp. 34-44.

Fifka, M.S. (2013), "Corporate responsibility reporting and its determinants in comparative perspective: a review of the empirical literature and a meta analysis", Business Strategy and the Environment, Vol. 22, pp. 1-35.

Figge, F. and Hahn, T. (2004), "Sustainable value added - measuring corporate contributions to sustainability beyond eco-efficiency", Ecological Economics, Vol. 48 No. 2, pp. 173-187.

Garcia, S., Cintra, Y., Rita de Cássia, S.R. and Lima, F.G. (2016), "Corporate sustainability management: a proposed multi-criteria model to support balanced decision-making", Journal of Cleaner Production, Vol. 136, pp. 181-196.

Garson, G.D. (2016), Partial Least Square: Regression and Structural Equation Models, Statistical Associates Publishing, North California.

Ghozali, I. and Latan, H. (2012), Partial Least Squares - The Concept, Technique, and Application of SmartPLS 2.0 M3, Universitas Diponegoro, Semarang.

Hair, J.F., Hult, G.T.M., Ringle, C. and Sarstedt, M. (2013), A Primer on Partial Least Squares Structural Equation Modelling (PLS-SEM), SAGE Publications, California.

Hair, J., Hollingsworth, C.L., Randolph, A.B. and Chong, A.Y.L. (2017), “An updated and expanded assessment of PLS-SEM in information systems research", Industrial Management and Data Systems, Vol. 117 No. 3, pp. 442-458.

Harrington, H.J., Esseling, E.C. and Van Nimwegen, H. (1997), Business Process Improvement Documentation, Analysis, Design and Management of Business Process Improvement, McGraw-Hill, New York, NY.

Hartono, B., FN Wijaya, D. and Arini, H. M. (2014), “An empirically verified project risk maturity model: evidence from Indonesian construction industry”, International Journal of Managing Projects in Business, Vol. 7 No. 2, pp. 263-284.

Hervani, A.A., Helms, M.M. and Sarkis, J. (2005), "Performance measurement for green supply chain management", Benchmarking: An International Journal, Vol. 12 No. 4, pp. 330-353.

Huang, Y.Y. and Handfield, R.B. (2015), "Measuring the benefits of ERP on supply management maturity model: a 'big data' method", International Journal of Operations and Production Management, Vol. 35 No. 1, pp. 2-25.

Iraldo, F., Testa, F. and Frey, M. (2009), "Is an environmental management system able to influence environmental and competitive performance? The case of the ecomanagement and audit scheme (EMAS) in the European union", Journal of Cleaner Production, Vol. 17 No. 16, pp. 1444-1452.

Islam, N. and Brousseau, E. (2014), "Implementing a multi-staged methodology to micro and nanotechnology: technology maturity assessment and framework", International Journal of Productivity and Performance Management, Vol. 63 No. 2, pp. 170-193.

Jasiński, D., Meredith, J. and Kirwan, K. (2016), “A comprehensive framework for automotive sustainability assessment”, Journal of Cleaner Production, Vol. 135, pp. 1034-1044.

Jin, D., Chai, K.H. and Tan, K.C. (2014), "New service development maturity model”, Managing Service Quality: An International Journal, Vol. 24 No. 1, pp. 86-116.

Johnson, R.B., Onwuegbuzie, A.J. and Turner, L.A. (2007), "Toward a definition of mixed methods research", Journal of Mixed Methods Research, Vol. 1 No. 2, pp. 112-133. 
Kaplan, R.S. and Norton, D.P. (2000), Putting the Balanced Scorecard to Work, Harvard Business Review OnPoint, Boston, Mass.

Katuu, S. (2016), "Assessing the functionality of the enterprise content management maturity model", Records Management Journal, Vol. 26 No. 2, pp. 218-238.

Killen, C.P. and Hunt, R.A. (2013), "Robust project portfolio management: capability evolution and maturity", International Journal of Managing Projects in Business, Vol. 6 No. 1, pp. 131-151.

Krippendorff, K. (2012), Content Analysis: An Introduction to its Methodology, SAGE Publishing, New York, NY.

Laszlo, C. and Zhexembayeva, N. (2011), Embedded Sustainability: The Next Big Competitive Advantage, Greenleaf, Sheffield.

Lin, Y., Cheng, H.P., Tseng, M.L. and Tsai, J.C. (2010), "Using QFD and ANP to analyze the environmental production requirements in linguistic preferences", Expert Systems with Applications, Vol. 37 No. 3, pp. 2186-2196.

Littell, J.H., Corcoran, J. and Pillai, V. (2008), Systematic Reviews and Meta-Analysis, Oxford University Press, Oxford.

MajalahCSR.id (2017), Indonesian Organization Has Low Interest on Making Sustainability Report (SR), PT DASA Strategik Indonesia, Jakarta.

Macchi, M. and Fumagalli, L. (2013), "A maintenance maturity assessment method for the manufacturing industry”, Journal of Quality in Maintenance Engineering, Vol. 19 No. 3, pp. 295-315.

Maletič, M., Maletič, D., Dahlgaard, J.J., Dahlgaard-Park, S.M. and Gomišček, B. (2014), "Sustainability exploration and sustainability exploitation: from a literature review towards a conceptual framework", Journal of Cleaner Production, Vol. 79, pp. 182-194.

Michelon, G., Boesso, G. and Kumar, K. (2013), "Examining the link between strategic corporate social responsibility and company performance: an analysis of the best corporate citizens", Corporate Social Responsibility and Environmental Management, Vol. 20 No. 2, pp. 81-94.

Morioka, S.N. and de Carvalho, M.M. (2016), "A systematic literature review towards a conceptual framework for integrating sustainability performance into business", Journal of Cleaner Production, Vol. 136, pp. 134-146.

Moullin, M. (2007), "Performance measurement definitions, Linking performance measurement and organisational excellence", International Journal of Health Care Quality Assurance, Vol. 20 No. 3, pp. $181-183$.

Okongwu, U., Morimoto, R. and Lauras, M. (2013), "The maturity of supply chain sustainability disclosure from a continuous improvement perspective", International Journal of Productivity and Performance Management, Vol. 62 No. 8, pp. 827-855.

Oliva, F.L. (2014), "Knowledge management barriers, practices and maturity model", Journal of Knowledge Management, Vol. 18 No. 6, pp. 1053-1074.

Parker, D.W., Loh, A., Chevers, D., Minto-Coy, I. and Zeppetella, L. (2017), "Operations sustainability maturity model: preliminary findings of financial services in developing and developed countries", Measuring Business Excellence, Vol. 21 No. 4, pp. 309-336.

Paulk, M.C., Weber, C.V., Curtis, B. and Chrissis, M.B. (1995), The Capability Maturity Model: Guidelines for Improving the Software Process, Addison-Wesley, Boston, MA.

Pekkola, S., Hildén, S. and Rämö, J. (2015), “A maturity model for evaluating an organisation's reflective practices”, Measuring Business Excellence, Vol. 19 No. 4, pp. 17-29.

Poppelbuss, J. and Roglinger, M. (2011), "What makes a useful maturity model? a framework of general design principles for maturity models and its demonstration in business process management", Proceedings of the European Conference on Information Systems, Association For Information Systems, Atlanta.

Rahdari, A.H. and Rostamy, A.A.A. (2015), "Designing a general set of sustainability indicators at the corporate level”, Journal of Cleaner Production, Vol. 108, pp. 757-771.

\section{Corporate} sustainability maturity model 
Ramadan, N. and Arafeh, M. (2016), "Healthcare quality maturity assessment model based on quality drivers", International Journal of Health Care Quality Assurance, Vol. 29 No. 3, pp. 337-350.

Rendon, R.G. (2015), "Benchmarking contract management process maturity: a case study of the US Navy", Benchmarking: An International Journal, Vol. 22 No. 7, pp. 1481-1508.

RobecoSAM (2017), Measuring Intangibles, RobecoSAM's Corporate Sustainability Assessment Methodology, RobecoSAM, Zurich.

Roca, L.C. and Searcy, C. (2012), "An analysis of indicators disclosed in corporate sustainability reports", Journal of Cleaner Production, Vol. 20 No. 1, pp. 103-118.

Salzmann, O., Ionescu-Somers, A. and Steger, U. (2005), "The business case for corporate sustainability: literature review and research options", European Management Journal, Vol. 23 No.1, pp. 27-36.

Sari, Y., Hidayatno, A., Suzianti, A. and Hartono, M. (2019), "A systematic literature review for developing sustainability assessment tool: formulating the state of the art and future direction", IOP Conference Series: Materials Science and Engineering, Vol. 703, p. 012018.

Sarwono, J. and Narimawati, U. (2015), Writing Research Report, Thesis and Dissertation by Using Partial Least Square SEM (PLS-SEM), Andi Publishing, Yogyakarta.

Secundo, G., Elena-Perez, S., Martinaitis, Ž. and Leitner, K.H. (2015), “An intellectual capital maturity model (ICMM) to improve strategic management in European universities: a dynamic approach", Journal of Intellectual Capital, Vol. 16 No. 2, pp. 419-442.

Secundo, G., De Beer, C. and Passiante, G. (2016), "Measuring university technology transfer efficiency: a maturity level approach”, Measuring Business Excellence, Vol. 20 No. 3, pp. 42-54.

Sharma, T. and Balachandra, P. (2015), "Benchmarking sustainability of Indian electricity system: an indicator approach”, Applied energy, Vol. 142, pp. 206-220.

Sholihin, M. and Ratmono, D. (2013), "SEM-PLS analysis with WarpPLS 3.0 for nonlinear relationships in social and business research", Andi Publishing, Yogyakarta.

Souza, R.P., Guerreiro, R. and Oliveira, M.P.V. (2015), "Relationship between the maturity of supply chain process management and the organisational life cycle", Business Process Management Journal, Vol. 21 No. 3, pp. 466-481.

Suwartha, N. and Sari, R.F. (2013), "Evaluating UI GreenMetric as a tool to support green universities development: assessment of the year 2011 ranking”, Journal of Cleaner Production, Vol. 61, pp. $46-53$.

Tan, H.X., Yeo, Z., Ng, R., Tjandra, T.B. and Song, B. (2015), "A sustainability indicator framework for Singapore small and medium-sized manufacturing enterprises”, Procedia Cirp, Vol. 29, pp. 132-137.

Terouhid, S.A. and Ries, R. (2016), "Organizational sustainability excellence of construction firms - a framework", Journal of Modelling in Management, Vol. 11 No. 4, pp. 911-931.

Tontini, G., de Carvalho, L.C., Schlindwein, N.F.D.C. and Tomarevski, V. (2016), "Maturity model of procurement and supply management in small and medium-size enterprises: a benchmarking of hospitals and metal-mechanic companies", International Journal of Quality and Service Sciences, Vol. 8 No. 3, pp. 315-333.

Tranfield, D., Denyer, D. and Smart, P. (2003), "Towards a methodology for developing evidenceinformed management knowledge by means of systematic review", British Journal of Management, Vol. 14 No. 3, pp. 207-222.

Vaismoradi, M., Turunen, H. and Bondas, T. (2013), "Content analysis and thematic analysis: implications for conducting a qualitative descriptive study", Nursing and Health Sciences, Vol. 15 No. 3, pp. 398-405.

van Lith, J., Voordijk, H., Matos Castano, J. and Vos, B. (2015), “Assessing maturity development of purchasing management in construction”, Benchmarking: An International Journal, Vol. 22 No. 6, pp. 1033-1057.

Wilson, F. (2015), “The Quality Maturity Model: your roadmap to a culture of quality”, Library Management, Vol. 36 No. 3, pp. 258-267. 
Woo, S.H., Pettit, S.J. and Beresford, A.K. (2013), "An assessment of the integration of seaports into supply chains using a structural equation model”, Supply Chain Management: An International Journal, Vol. 18 No. 3, pp. 235-252.

Xiaofen, T. (2013), "Investigation on quality management maturity of Shanghai enterprises", The TQM Journal, Vol. 25 No. 4, pp. 417-430, doi: 10.1108/17542731311314890.

Young, W. and Tilley, F. (2006), "Can businesses move beyond efficiency? The shift toward effectiveness and equity in the corporate sustainability debate", Business Strategy and the Environment, Vol. 15 No. 6, pp. 402-415.

\section{About the authors}

Yenny Sari is an Assistant Professor at the Department of Industrial Engineering, University of Surabaya, Indonesia. She holds a B.Eng. Degree in Industrial Engineering from the University of Surabaya in 2001. She received the Technological and Professional Skills Development Project grant for her Master of Science in Operations Management from the University of Birmingham, the United Kingdom, in 2005. She is now pursuing her doctoral degree in Universitas Indonesia with financial support from her university. Her research interest covers sustainability performance and quality management.

Akhmad Hidayatno is an Associate Professor and the Head of Systems Engineering, Modeling, and Simulation Laboratory, Universitas Indonesia. Graduated from Industrial Engineering from Universitas Indonesia, obtained Master of Business and Technology from Australian School of Business, University of New South Wales, Australia, and a Doctorate Degree in Chemical Engineering, Universitas Indonesia, has given him a unique perspective on how the industry and sustainability are interrelated systemically. His research focuses on exploring the triangle of Energy, Industry, and Sustainability, with interest in renewable energy and technological change. He is a member of System Dynamics Society (SDS), International Council of Systems Engineering (INCOSE), and Institute of Industrial and Systems Engineers (IISE). Akhmad Hidayatno is the corresponding author and can be contacted at: akhmad. hidayatno@ui.ac.id

Amalia Suzianti is an Associate Professor in the Department of Industrial Engineering, Faculty of Engineering, Universitas Indonesia. She holds a Ph.D. in Innovation System Design from Technische Universitaet Berlin, Germany, and the University of Luxembourg, a Master of Science in Technology and Innovation Management from Brandenburgische Technische Universitaet Cottbus, Germany and a Bachelor of Engineering in Industrial Engineering from Universitas Indonesia. Before joining Universitas Indonesia in late 2010, she has acquired international academic and professional work experiences, mainly in Europe, Asia, and Latin America. She was involved in various multinational projects in different industries. Her research interests lie in the fields of New Product and Service Development, Technology and Innovation Management, Technology Policy, and Sustainable Innovation. She is also a member of the Product Development and Management Association (PDMA) and Design Society (DS).

Markus Hartono is an Associate Professor at the Department of Industrial Engineering, University of Surabaya, Indonesia. He holds a B.Eng. Degree in Industrial Engineering from the University of Surabaya in 2000. He received the ASEAN Graduate Scholarships award for his Master of Science in 2005 and received an NUS Graduate Research Scholarships for his Ph.D. in 2012, majoring in Industrial Engineering. He has published more than 25 research articles in top tier international journals and reputable international conferences. He is a Certified Human Factors Professional (CHFP), ASEAN Engineer, and a member of the International Ergonomics Association (IEA) Affective Design Technical Committees.

Harman Susanto was a full-time student who completes his bachelor's degree in Industrial Engineering from the University of Surabaya in 2018 with his specialized concentration on the sustainable enterprise system.

For instructions on how to order reprints of this article, please visit our website:

www.emeraldgrouppublishing.com/licensing/reprints.htm

Or contact us for further details: permissions@emeraldinsight.com 


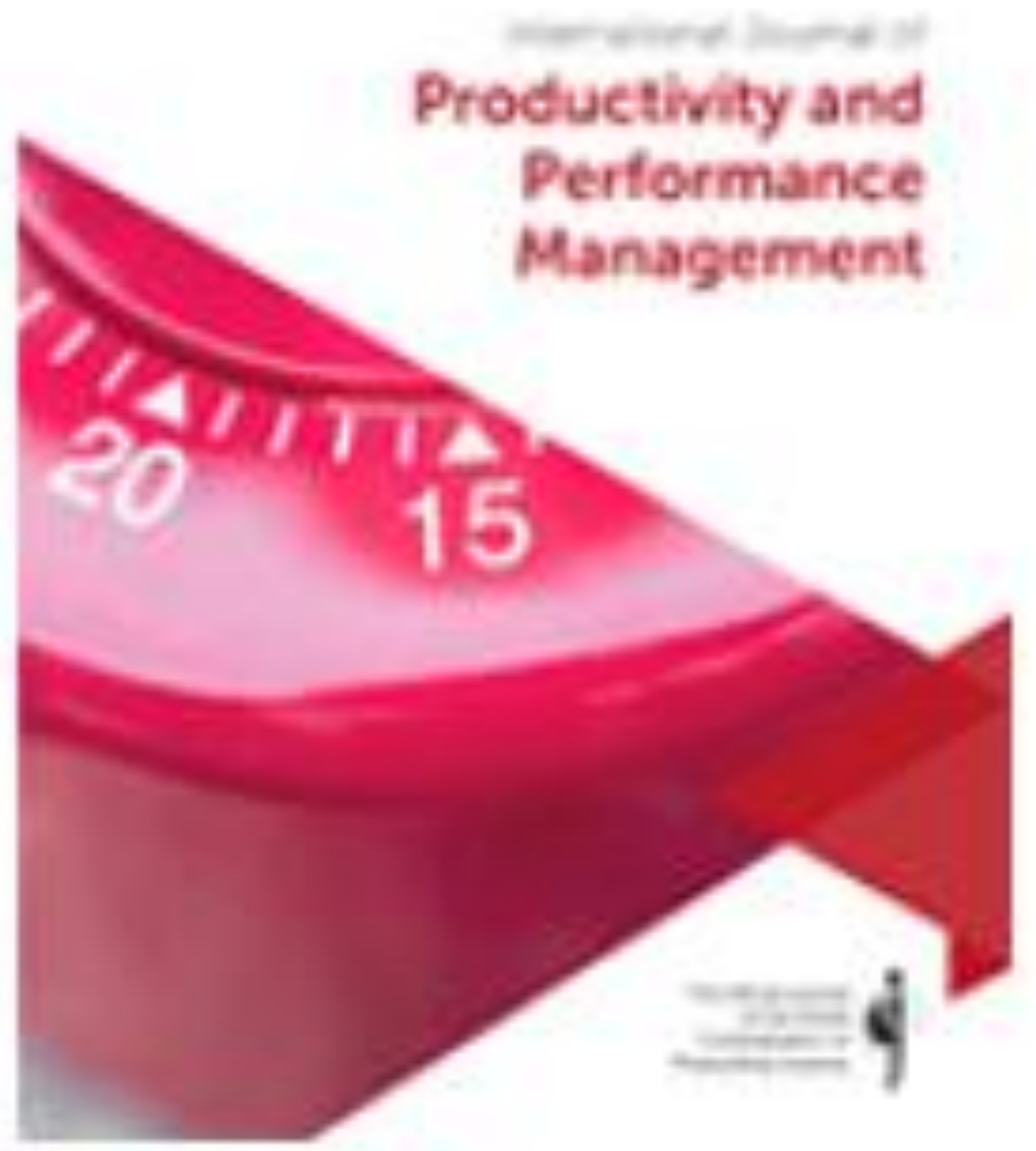




\title{
Co-Editor
}

\author{
Dr Luisa Huaccho Huatuco \\ University of York - UK \\ luisa.huatuco@york.ac.uk \\ Dr Nicky Shaw \\ Leeds University Business School - UK \\ N.E.Shawalubs.leeds.ac.uk
}

\section{Editorial Assistant}

Jennifer Webster

University of Leeds - UK

jeniwebster123@gmail.com

\section{Regional Editor}

Dr Cláudia S Sarrico (Europe)

Technical University of Lisbon - Portugal

\section{Associate Editor}

Dr. Berk Kucukaltan

School of Applied Sciences, Trakya University - Turkey

berkkucukaltan@ trakya.edu.tr

Professor Sai Sudhakar Nudurupati

Gandhi Institute of Technology and Management University - India snudurup@gitam.edu

Professor Arash Shahin

University of Isfahan - Iran

shahinaase.ui.ac.ir

Dr. Jitesh J. Thakkar

National Rail and Transportation Institute (NRTI) - India

jitesh.thakkar@nrti.edu.in

Dr Lihong Zhang

University of Manchester - UK

Lihong.Zhang@manchester.ac.uk

\section{Publisher}

Daniel Ridge

Emerald Group Publishing - USA

dridgeaemeraldgroup.com 
Journal Editorial Office (For queries related to pre-acceptance)

Sharon Sebastian Kanappally

Emerald Publishing

sharon.emerald@kwglobal.com

Supplier Project Manager (For queries related to post-acceptance)

Subha Arounkumar

Emerald Publishing

subha.emerald@atnq.co.in

\section{Editorial Advisory Board}

Dr Rabiul Ahasan

King Saud University - Saudi Arabia

Professor Eileen van Aken

Virginia Tech - USA

Professor Bjorn Andersen

Norwegian University of Science \& Technology - Norway

Professor Jiju Antony

Edinburgh Business School, Heriot Watt University - UK

Professor Umit Sezer Bititc

Edinburgh Business School, Heriot Watt University - UK

Professor Mike Bourne

Cranfield School of Management - UK

Dr Thomas F Burgess

Leeds University Business School - UK

Dr Yu-wang Chen

The University of Manchester - UK

Dr Ibrahim Duyar

University of Arkansas Little Rock - USA

Dr Patrizia Garengo

University of Padova - /taly

Dr. Richard Greatbanks

University of Otago - New Zealand

Professor Claire Hannibal.

Liverpool John Moores University - UK

Professor Rajashekharaiah Jagadeesh

SDM Institute for Management Development - India

Professor Wagner Cezar Lucato

Nove de Julho University - Brazil

Professor Jill MacBryde

University of Strathclyole - UK

Dr Jane Maley

Charles Sturt University - Australia

Dr Kepa Mendibil

University of Strathclyole - UK

Dr Matteo Mura

University of Bologna - Italy

Professor Sai Nudurupat

Gandhi Institute of Technology and Management - India

Professor Low Sui Pheng

National University of Singapore - Singapore 
Professor Zoe Radnor

University of Law - UK

Professor Nick Rich

Swansea University - UK

Dr Sanjay Kumar Singh

School of Business, Maynooth University, Maynooth - Ireland

Dr. Narayanasamy Sivasankaran

XLRI Xavier School of Management - India

Dr Alison Smart

University of Glasgow - UK

Professor Amrik Sohal

Monash University - Australia

Dr Mike Tse

Cardiff University - UK

Dr Morteza Yazdani

ESIC Business \& Marketing School - Spain

Professor Li Zheng

Tsinghua University - People's Republic of China

Dr Andre A de Waal.

Wittenborg University of Applied Sciences - The Netherlands 


\section{International Journal of Productivity and Performance \\ Management: volume 70 Issue 5 \\ Category: Performance Management and Measurement}

Subscribe to table of contents alerts

Table of contents

\section{Editorial}

Ilias Vlachos, Morgane Fritz, Salomée Ruel, Vikas Kumar

is $\mathrm{PDF}(62 \mathrm{~KB})$

Applying Industry 4.0 technologies in the COVID-19 sustainable chains Carina Acioli, Annibal Scavarda, Augusto Reis

it $\mathrm{PDF}(635 \mathrm{~KB}$

The purpose of this paper is 1) to investigate the effects on the crucial Industry 4.0

4 Roperms s Permissions technological innovations that interact between the real and virtual worlds and that...

The current sustainability scenario of Industry 4.0 enabling technologies in Indian manufacturing industries

Bhaveshkumar Nandanram Pasi, Subhash K. Mahajan, Santosh B. Rane

it $\operatorname{PDF}(1.9 \mathrm{MB})$

4 Reprims 4 Permisiosions

The purposes of this research article are as follows: to explore the understanding of the Industry 4.0 (14.0) concept among Indian manufacturing industries, to determine...

Assessing the key enablers for Industry 4.o adoption using MICMAC analysis: a case study

사 $\mathrm{PDF}(761 \mathrm{~KB}$.

Srijit Krishnan, Sumit Gupta, Mathiyazhagan Kaliyan, Vikas Kumar, Jose Arturo Garza-

Reyes

The aim of this research is to assess the key enablers of Industry $4.0(14.0)$ in the context of the Indian automobile industry. It is done to apprehend their comparative... 
Engineering companies and their readiness for Industry 4.0

This case study of the readiness of engineering companies for Industry $4.0(14.0)$ presents how surveyed key figures manage the implementation of 14.0. The research...

Fifteen years of international journal of productivity and performance management (2004-2018)

Riya Sureka, Satish Kumar, Sachin Kumar Mangla, Flavio Hourneaux Junior International Journal of Productivity and Performance Management (IJPPM) is one of the prominent journals publishing on general management with a particular focus on...

An empirical investigation of the relationship between TSR, value-based and accounting-based performance measures

Harnesh Makhija, Pankaj Trivedi

The paper aims to find out the information content of performance measures from accounting and value-based measures that best explain the total shareholder return.

How is responsible leadership related to the three-component model of organisational commitment?

Amlan Haque, Mario Fernando, Peter Caputi

The increasing number of corporate scandals and averseness to employee commitment have brought the concept of responsible leadership (RL) to the forefront of... 
A corporate sustainability maturity model for readiness assessment: a three-step development strategy

Yenny Sari, Akhmad Hidayatno, Amalia Suzianti, Markus Hartono, Harman Susanto

One of the main challenges of organisations today is how to navigate their development into ideal sustainable organisations. However, each readiness level requires a...

Successful business models for service centres: an empirical analysis

Paolo Gaiardelli, Lucrezia Songini

8 Reprints \& Permissions

The purpose of this paper is to analyse the fit between the strategy of service centres and their business model (BM) and to identify the BM components' characteristics...

The mark of industry 4.0: how managers respond to key revolutionary changes

The purpose of this study is to provide a framework of managerial responses to the Industry 4.0 phenomenon, which has impacted the productivity of Indonesian manufacturing... 